\title{
Improving the Cultural Competency of Midwives on Maternal and Child's Health Services in Sa'dan North Toraja
}

\author{
Weny Lestari \\ Social Culture and Health Laboratory, National Institute of Health Research and Development, Ministry of Health-
}

Republic of Indonesia, Surabaya, Indonesia

e-mail:weny716@gmail.com

\begin{abstract}
Maternal and neonatal deaths, and delivery's coverage at healthcare still be problems in North Toraja. Culture was one of factors that influence unsafe delivery. It's important for midwives to understand culture in community. The objectives of this study were to improve midwives' cultural competency and to minimalize cultural barriers. Cultural competency had been trained to 19 midwives in Sa'dan North Toraja. Training contained material of the culture of pregnancy and childbirth. Through roleplay regarding cultural problems faced by midwives in community and how they learned from each other to find solutions to cultural barriers in their duties. Roleplay's themes had been founded together contains about how to: (1) socialization to family member of traditional midwife (to 'mappakianak) that not allowed to help delivery; (2) convincing woman to deliver at healthcare; (3) minimize the gap between midwives and community; (4) convincing delivery decision making in extended family; (5) resolve problem of cultural role of mother in family, by involving, discussion and collaboration with parents, family members, and respectable community leaders. It concluded that improving cultural competency could minimalize cultural barriers in community. Communication between midwives and communities were the key of improvement maternal and child's health services.
\end{abstract}

Keywords-Cultural Competency, Health Services, Midwives, Safe Delivery.

\section{INTRODUCTION}

$\mathrm{T}$ HE number of maternal and neonatal mortality (ages 029 days) in North Toraja in years 2017-2018 were high. Maternal mortality was 1 case in 2017 and 5 cases in 2018, while neonatal mortality were 28 cases in 2017 and 18 cases in 2018[1][2].

Maternal mortality according to the World Health Organization's definition was death during pregnancy or within a period of 42 days after the end of pregnancy, due to all causes related to or aggravated by pregnancy or its handling, but not due to injury/accident. The cases number of maternal and child mortality in North Toraja District from 2012 to 2018 could be seen on the Table 1 above [2]. There were 201 cases of child mortality in seven years period, most of cases were neonatal deaths about 142 cases with various causes.

Maternal and child mortality cases causes by: (1) there were unsafe deliveries which assisted by traditional midwives (to' mappakianak); (2) The distance between the house and health care facilities, average from 5-10 kilometre with difficult accessability; (3) Women ages were relatively young for pregnancy and childbirth; (4) Approximately $20 \%$ of midwives in North Toraja District did not live in the village they placed because the lack of supporting facilities in health service[2].

The coverage of deliveries assisted by health workers in North Toraja were 63\%, while at Sa'dan Sub District area were $56 \%[2]$. These condition were not different from previous 5 years before, based on data of Basic Health Research in 2013 showed that in North Toraja Regency there were $32.2 \%$ of deliveries assisted by non-health workers (traditional birth attendants, family/others, or there were no birth attendants/self delivering childbirth), and $57.1 \%$ of deliveries were still carried out at home[3]. Datas of Ethnographic's Health Research in 2012[4] and Research of Health Intervention in 2017[2] showed that culture was one of the factors that influenced unsafe childbirth delivery conditions in North Toraja Regency.

The culture of pregnancy and childbirth in Sa'dan North Toraja was having a large number of children still be the dream of the family, an average of 3-5 children or more. The value of having many children were high in Toraja's culture, especially at the traditional ritual of Rambu Solo' (burial ceremony of death). The gifts in Rambu Solo' from other families who were presence would be calculated as debts which be carried and shared in nuclear family. It would be more lighter debt when having a lot of family members[4]. In addition, there were many unsafe deliveries reasons. As examples like births carried out at home, giving birth alone and/or assisted by the to' mappakianak (traditional birth attendants), mothers' experiences of childbirth on their own, and feeling uncomfortable of giving birth in health facilities due to service problems that are less sympathetic and/or the age matter of health workers. In Toraja culture, young people were considered inexperienced, meanwhile midwives as health workers in Sa'dan North Toraja in the average young ages (under 30 years) [2].

Therefore, it was important for health workers, especially midwives whose duties in villages, to understand the culture of the community in where they worked with. Cultural understanding was important, because culture influenced the concept of the meaning of health and sickness, of how humans explain the concept of disease, health-seeking behavior, the useful functions of the health system, relationships with health care providers, and acceptance of medicine. Increasing the cultural competence of village midwives is very important because knowledge, attitudes, and behavior are needed to improve the quality of services to people with certain cultures, by accepting and respecting different concepts, namely between the concept of health in 
Table 1.

The Cases Number Of Maternal and Child Mortality In North Toraja 2012-2018

\begin{tabular}{ccccc}
\hline \hline Year & $\begin{array}{c}\text { Number } \\
\text { of } \\
\text { Maternal } \\
\text { Mortality }\end{array}$ & $\begin{array}{c}\text { Number } \\
\text { of } \\
\text { Neonatus } \\
\text { Mortality } \\
\mathbf{( 0 - 2 8 d )}\end{array}$ & $\begin{array}{c}\text { Number } \\
\text { of Child } \\
\text { Mortality } \\
\text { (29d- } \mathbf{1 y})\end{array}$ & $\begin{array}{c}\text { Numbe } \\
\text { of Chil } \\
\text { under } \\
\mathbf{5 y} \\
\mathbf{( 1 y -} \\
\mathbf{5 9 m})\end{array}$ \\
\hline 2012 & 12 & 23 & & 2 \\
2013 & 2 & 15 & 7 & 4 \\
2014 & 3 & 17 & 5 & 3 \\
2015 & 2 & 18 & 5 & 1 \\
2016 & 5 & 23 & 7 & 2 \\
2017 & 1 & 28 & 8 & 2 \\
2018 & 5 & 18 & 7 & 1 \\
\hline Total & $\mathbf{3 0}$ & $\mathbf{1 4 2}$ & $\mathbf{4 4}$ & $\mathbf{1 5}$ \\
\hline \hline
\end{tabular}

the program and the concept of health culture in the community[4].

The objectives of this study were would to (1) achieved coverage of safe deliveries that were carried out in health facilities and assisted by midwives in the working area of the Sa'dan Primary Health Center (Puskesmas), North Toraja District, and (2) increased public trust on midwives in providing comfortable services and minimizing misunderstanding of communication between parties.

\section{METHOD}

Cultural competency had been trained to 19 midwives which consisted 13 midwives who worked in villages, 1 midwive as coordinator, and other midwives worked as internship at Sa'dan Primary Health Center, Sa'dan Sub District, North Toraja. Cultural Competency Training contained material of the culture of pregnancy and childbirth. Through roleplay regarding cultural problems faced by midwives in community and how they learned from each other to find solutions to cultural barriers in their duties.

Pre and Post Test Cultural Competency Questionnaires were also given to 19 midwives. Pre test held on the first meeting before cultural competency training, and pre test held after cultural competency training. There were three categories of statements of midwives related to cultural competency, namely (1) conditions of the physical, material and resource environment; (2) communication; and (3) attitude. Pre and Post Test only described before-after questionary result qualitatively in description tables, not to be statistically tested.

\section{RESULT AND DISCUSSION}

\section{A. Health Services in Sa'dan Sub District}

North Toraja was the one of the districts in South Sulawesi Province, which has been separated area of Tana Toraja District since the year of 2008. Sa'dan is one of 21 subdistricts in North Toraja District which had 10 villages. Health services in the Sa'dan sub-district relied on one Primary Health Services (Puskesmas) which was located in Sangkaropi Village area. Sa'dan Primary Health Services had 9 Village's Health Services (Puskesmas Pembantu/ Pos Kesehatan Desa) in 8 villages, with midwife as the head area responsibility[1].
Table 2.

Personnels Of Sa'dan Primary Health Center 2018

\begin{tabular}{cc}
\hline \hline Personnels & Total \\
\hline Doctor & 1 \\
Dentist & 1 \\
Nurse & 19 \\
Midwife & 32 \\
Public Health & 1 \\
Environment Health & 1 \\
Medic Laborat & 0 \\
Nutritionist & 2 \\
Pharmacist & 1 \\
Phisioterapist & 1 \\
Administration & 3 \\
\hline Total & $\mathbf{6 2}$ \\
\hline \hline
\end{tabular}

The waiting house of delivery (Rumah Tunggu Kelahiran/RTK) was established in the Sa'dan Sub District area side by side with Sa'dan Primary Health Center in early year of 2018. RTK established for cutting the distance between location of pregnant women and health services before the day of delivery. The use of RTK has increased significantly since it established. On July 2018 there were 45 pregnant women and on November 2018 there were 78 pregnant women who used RTK[2].

The total number of personnel in Sa'dan Primary Health Center in 2018 were 62 personnels, with details in Table 2 above. 32 midwives in Sa'dan consisted of 12 civil servants, 1 non permanent officer, 13 honorary personnels, and 6 internships.

\section{B. Cultural Matter in Pregnancy and Childbitrh in Sa'dan North Toraja}

In Sa'dan Sub District, young families have an average of 3 - 5 children. In the previous generation, the number of children in a family reached an average of 7-15 children. In more remote Sa'dan areas such as village of Ballo Pasange, Sangkaropi, and Ulusalu, young families still have children on average between 5-10 children.

The age of women marriage were relatively young. Sa'dan's women usually married in their teens age, especially women who lived on mountainous areas far from district. There was a woman at the age of 25 years who already had five children. There was also a 35 years old woman who recently had grandchildren from her first daughter which age was 21 years old. In areas that were relatively close to the district city the average age of marriage for women were 20 years old and for men around 25-30 years old. When there were people who are old enough to get married but not yet married, parents and extended family (relatives) would participate in providing matchmaking choices for them, both from their own family and/or from other circles family.

The condition of the mountainous geographical area, with rocky road access, only some of which have been paved or cast, so local people had adaptations in their lives. Their adaptations included of the problems with pregnancy and childbirth. Women in the Sa'dan sub-district are used to giving birth by themselves at home without any help, only their families. They already had cultural knowledge about how to give birth by themselves at home. Sa'dan women had psychological calm in giving birth to their babies at home. In addition to relatively remote access to health services, this also had risks for their pregnancy. The reluctance of Sa'dan 
The $2^{\text {nd }}$ International Conference on Global Development - ICODEV

December $5^{\text {th }}, 2020$, Online Conference

women to give birth in health care facilities was due to remote accessibility. It also about their cultural roles in family that women's responsibility to feed livestock (pigs), and gardens/fields. Another reasons of reluctance were problem of comfortable place to deliver and the lack of trust in younger midwives who assumed to be less experienced.

There were patrons in the kinship of the Sa'dan people. Patrons were the most respected people in the family and had a great influence on the families within the patron's sphere. They could influenced the family decision making, that included of the decision of where the pregnant women in the family would be delivering their babies.

A pregnant woman in Sa'dan had the courage to take the decision to give birth her own baby by herself, because she had culturally acquired knowledge of childbirth from the previous generation and was trained to assist with childbirth on her own within her extended family. Delivery knowledge also got from their environmental groups who told each other regarding the birth process itself, about what was considered good or bad for pregnancy and in the process of childbirth.

Psychological confidence and comfort related to calmness, focus on the actions to be taken, and the atmosphere of not being pressured in the delivery process were also a consideration why some women in Sa'dan chose to give birth their babies at home rather than at health care facilities.

The geographical conditions of the mountains, which were hilly up and down, make women accustomed to walking up and down when they carried out their daily activities. From childhood they were used to the conditions of the mountainous region. They have more power and a longer breath than urban people with sedentary activities, and were spoiled for good road conditions and affordable transportation. This was what distinguishes the physical condition of pregnant women in the Sa'dan Toraja area, from those of pregnant women in general in urban areas. Their daily activities since childhood have been conditioned by nature.

However, with the confidence to give birth a baby by themselves, pregnant women in Sa'dan Toraja did not necessarily trust the available health services related to maternal and child health. Most of the women who gave birth their babies by themselves stated that they routinely checked their pregnancies at Posyandu and checked by obgyn doctors. After giving birth, they also routinely brought their babies every month to Posyandu for getting complete immunizations.

\section{Role Play of Cultural Competency}

The thematics role play of the culture of pregnancy and childbirth in Sa'dan were derived from the problems faced by midwives in providing maternal and child's health services in the community. Performed by midwives' themselves, they were divided into 5 groups of role play themes, and problems were discussed and solved together, facilitated by facilitators from the socio-cultural science of health, communication, and community midwifery.

Role play was formed from description of cultural problems in community, training how to :
1) Socialize to elderly to 'mappakianak (traditional birth attendants) not to help childbirth anymore, and socialize to residents whose family members of to 'mappakianak, but they want to give birth at a health facility and be helped by midwives.

To' mappakianak who was a pregnant mother's grandmother, tried to influence her grand daughter to give birth at home. However, mother who always checked her pregnancy at the healthcare and midwife discussed the risks of delivery with her grandmother, and called the midwife to come to her house to explain to her grandmother. Since $t^{\prime}$ mappakianak as a grandmother was an influential elder, midwife took the initiative to invite the head of village as a community leader to provide the understanding to the community.

2) Pregnant women who planned to delivery by themselves at home because they feel that they have experienced giving birth many children and there were no obstacle,. apart from reasons of access to affordability of health facilities and health workers.

The midwife explained about the risks of pregnancy and childbirth for high-risk pregnant women who plan to have their own birth at home. By involving parents and community leaders, the midwife conveyed that there was a waiting house for births near primary health center if the obstacles were accessibility and affordability. Pregnant women and a companion could be picked up by the PHC ambulance at the time of their due date to live in the waiting house, so they could be delivery at health facilities and helped by health workers, all facilitaties were free of charge, borne by the government.

3) Minimizing the gap between "outsiders" and "insiders" in their respective work areas, and increasing trust in the community even though some midwives were considered to be "outsiders" from the family clan environment.

The conditions that occured in Sa'dan community indicate a gap in accepting midwives who came from their village and midwives who were not origin from the village, eventhough the midwives origin from the same ethnic. Midwives who come from outside of the village would be get lack acceptance by the community, because they were considered as outsiders. One of the efforts made to minimize the gap that occurs was to involve the village community leaders.

People who think that midwives come from outside the village get an understanding from community leaders who was respected by the families in community. Midwives also try to involve community leaders in order to gain the trust of the community.

4) Pregnant women in making decisions about where they would childbirth in the scope of the extended family there were patrons (central figures in the family) who played a role in decision making.

Sa'dan people very respectfull to the patron (the central figure in the family) in their daily life. One of them was as a decision maker when women in family member were 
December $5^{\text {th }}, 2020$, Online Conference

Table 3.

Cultural Competency On Conditions Of The Physical Environment, Material and Resources Category

\begin{tabular}{|c|c|c|}
\hline Category & Pre test & Post test \\
\hline \multicolumn{3}{|l|}{ 1. Distance of Puskesmas/Pustu/Poskesdes to the community } \\
\hline All near & $0 \quad(0 \%)$ & $0 \quad(0 \%)$ \\
\hline Near and far & $19(100 \%)$ & $19(100 \%)$ \\
\hline \multicolumn{3}{|l|}{ 2. Heath equipment facilities } \\
\hline complete & $0 \quad(0 \%)$ & $0 \quad(0 \%)$ \\
\hline Less complete & $19(100 \%)$ & $19(100 \%)$ \\
\hline \multicolumn{3}{|l|}{ 3. Ambulance and driver Availibities } \\
\hline standby 24 hours & $3(16 \%)$ & $3(16 \%)$ \\
\hline Sometimes available & $2(10 \%)$ & $2(10 \%)$ \\
\hline Not available & $14(74 \%)$ & $14(74 \%)$ \\
\hline \multicolumn{3}{|l|}{ 4. Accessibility to childbirth waiting house } \\
\hline Near Pustu/Polindes & $0 \quad(0 \%)$ & $0 \quad(0 \%)$ \\
\hline Several villagers uncovered & $19(100 \%)$ & $19(100 \%)$ \\
\hline All villagers uncovered & $0(0 \%)$ & $0(0 \%)$ \\
\hline \multicolumn{3}{|l|}{ 6. Utility of Village's fund } \\
\hline Funding Puskesmas /Pustu/ Polindes & $14(74 \%)$ & $10(53 \%)$ \\
\hline Funding village road & $4(21 \%)$ & $5(26 \%)$ \\
\hline Not available & $1(5 \%)$ & $4(21 \%)$ \\
\hline \multicolumn{3}{|l|}{ 7. To'mappakianak in village } \\
\hline 1 people in 1 village & $7(37 \%)$ & $10(53 \%)$ \\
\hline $2-5$ peoples in 1 village & $5(26 \%)$ & $3(16 \%)$ \\
\hline$>5$ peoples in 1 village & $7(37 \%)$ & $6(32 \%)$ \\
\hline \multicolumn{3}{|l|}{ 8. Existance of To'mappakianak } \\
\hline Only as traditional midwife & $15(79 \%)$ & $13(69 \%)$ \\
\hline As elderly in families & $4(21 \%)$ & $5(26 \%)$ \\
\hline As village's elderly who obidience by community & $0 \quad(0 \%)$ & $1(5 \%)$ \\
\hline \multicolumn{3}{|l|}{ 11. Availability of health worker personnel } \\
\hline Nurse/other Midwife & $10(53 \%)$ & $10(53 \%)$ \\
\hline Non health worker & $0 \quad(0 \%)$ & $1(5 \%)$ \\
\hline Working alone & $9(47 \%)$ & $8(42 \%)$ \\
\hline
\end{tabular}

pregnant and where to give birth.

Collaboration between midwives and head of village to socialize safe delivery to the extended family of pregnant women, and the head of village approached and explained to the parents or patron of pregnant women who were the decision makers where the mother should give birth.

5) Pregnancy at risk and use of waiting house of delivery, and cultural clashes, the issue of who will replace the cultural role of mothers who take care of household affairs, look after other children and pigs.

The Primary Health Center has provided a waiting house of delivery which located next to the Sa'dan PHC building to be used by people waiting for the delivery process. Apart from that, the duties of women in household and taking care of livestock and other children were be considerations for giving birth at home.

The village midwife provided an explanation of the function of the waiting house of delivery to the families of pregnant women, and discussed to provide a solution regarding who would be replaced the women's role responsibility at home as long as the pregnant woman stayed in the waiting house.
Disscussion was held after role play was carried out to provide mutual input among health workers, improving midwives roles, and the opportunity for the District Health Authority to improve policy programs such as supporting system, optimalize and transparancy the use of health operatinal donors (Bantuan Operasional Kesehatan/BOK) for Primary Health Center funds for health promotion programs, especially in supporting the maternal and child's health services.

D. Pre and Post Test of Cultural Competency on Midwives

There were three categories of statements midwives related to cultural competency, (1) conditions of the physical environment, material and resources; (2) communication; and (3) values and attitudes.

\section{1) Conditions of the physical environment, material and resources category}

Conditions of the physical environment related to the distance of Puskesmas/Pustu/Poskesdes to the community, heath equipment facilities, ambulance and driver availibities, and accessibility to childbirth waiting house.

All midwives stated that the available health service facilities were accessible to the community, but there were 
Table 4.

Cultural Competency on Communication

\begin{tabular}{|c|c|c|c|}
\hline & Category & Pre test & Post test \\
\hline \multirow[t]{4}{*}{1.} & $\begin{array}{l}\text { Pregnancy class } \\
\text { availibity }\end{array}$ & & \\
\hline & $\begin{array}{l}\text { When midwife } \\
\text { available }\end{array}$ & $0 \quad(0 \%)$ & $0 \quad(0 \%)$ \\
\hline & Include with Posyandu & $10(53 \%)$ & $7(37 \%)$ \\
\hline & Routine special class & $9(47 \%)$ & $12(63 \%)$ \\
\hline \multirow[t]{4}{*}{2.} & $\begin{array}{l}\text { Matery of pregnancy } \\
\text { class }\end{array}$ & & \\
\hline & $\begin{array}{l}\text { Pregnancy exercise } \\
\text { every month }\end{array}$ & $1 \quad(5 \%)$ & $2(10 \%)$ \\
\hline & $\begin{array}{l}\text { Pregnancy exercise } \\
\text { and maternal and } \\
\text { child's health } \\
\text { promotion }\end{array}$ & $10(53 \%)$ & $10(53 \%)$ \\
\hline & $\begin{array}{l}\text { Pregnancy exercise } \\
\text { and maternal and } \\
\text { child's health } \\
\text { promotion every } \\
\text { months routinely }\end{array}$ & $8(42 \%)$ & $7(37 \%)$ \\
\hline \multirow[t]{4}{*}{3.} & Posyandu Activities & & \\
\hline & weighing & $0 \quad(0 \%)$ & $0 \quad(0 \%)$ \\
\hline & measurement & $0 \quad(0 \%)$ & $0 \quad(0 \%)$ \\
\hline & Recording KIA book & $\begin{array}{c}19 \\
(100 \%)\end{array}$ & $19(100 \%)$ \\
\hline \multirow[t]{4}{*}{4.} & $\begin{array}{l}\text { Infacing seniority of } \\
\text { pregnancy women and } \\
\text { their family }\end{array}$ & & \\
\hline & Surendered & $0 \quad(0 \%)$ & $0 \quad(0 \%)$ \\
\hline & Insisting & $0 \quad(0 \%)$ & $0 \quad(0 \%)$ \\
\hline & $\begin{array}{l}\text { Good approachment } \\
\text { and continueity }\end{array}$ & $\begin{array}{c}19 \\
(100 \%)\end{array}$ & $19(100 \%)$ \\
\hline \multirow[t]{4}{*}{5.} & $\begin{array}{l}\text { Creating sense of } \\
\text { security and comfort } \\
\text { during childbirth }\end{array}$ & & \\
\hline & Only doing the duty & $0 \quad(0 \%)$ & $0 \quad(0 \%)$ \\
\hline & $\begin{array}{l}\text { Only concern on safe } \\
\text { delivery }\end{array}$ & $0 \quad(0 \%)$ & $0 \quad(0 \%)$ \\
\hline & $\begin{array}{l}\text { Try to understand } \\
\text { maternity needs for } \\
\text { goal of safe delivery }\end{array}$ & $\begin{array}{c}19 \\
(100 \%)\end{array}$ & $19(100 \%)$ \\
\hline \multirow[t]{5}{*}{6.} & Communication Inter & & \\
\hline & $\begin{array}{l}\text { Sectorals for delivery } \\
\text { services }\end{array}$ & & \\
\hline & None & $0 \quad(0 \%)$ & $0 \quad(0 \%)$ \\
\hline & Rare & $12(63 \%)$ & $13(68 \%)$ \\
\hline & Routine & $7(37 \%)$ & $6(32 \%)$ \\
\hline
\end{tabular}

also people whose residences were far from the health facilities. All midwives also stated that the health equipment facilities were less complete, cause some midwives stated that they sometimes bought their own equipments by themselves.

Most midwives stated that there was no village's ambulance, however, there were already some midwives who stated that in their area there was an ambulance facility, and some even stated that an ambulance was ready to be on standby 24 hours whenever it needed.

Most of midwives stated that there was a childbirth waiting house near the Sa'dan primary health services. However, there were midwives who stated that the childbirth waiting house was not accessible cause of the distance. This first category conditions could seen on Table 3 .

Conditions of materials related to accessibility to health insurance for delivery and utility of village's fund. All midwives stated that some residents did not have insurance (KIS / BPJS Kesehatan). Most midwives stated that the use of village funds was also to support the activities of health services (Puskesmas/Pustu/Polindes). Several village's
Table 5.

Cultural Competency on Values and Attitudes

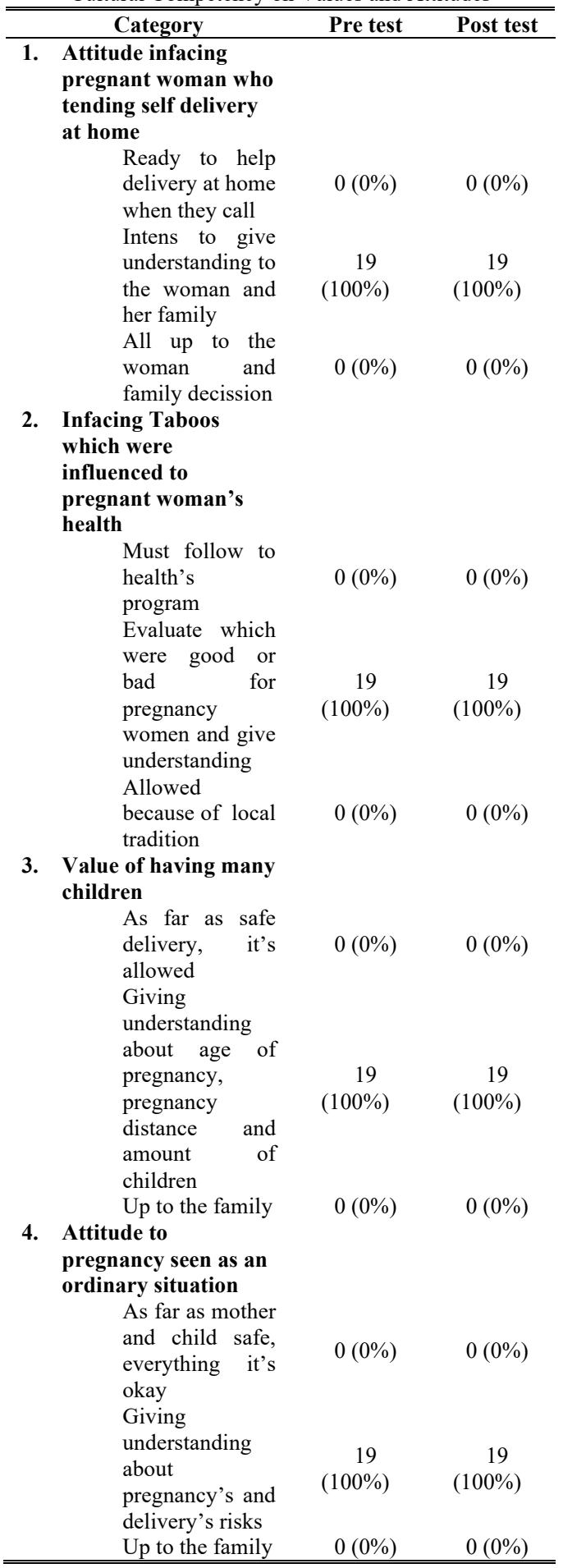

midwives in Sa'dan Sub District already had a good relations with the head of village, and had benefit from the use of Village's Fund for health services, including the fulfillment of facilities and infrastructure at Pustu/Poskesdes/Polindes. It also used for funding the health cadres in village. Although there were still village midwives who still lack communication with the head of the village and less actived in village meetings, so there were those who have not maximally utilized the $10 \%$ of village funds in the health sector, they need to be improved.

Cultural competence in terms of knowledge of human resources were related to the existence, number, age, and 
The $2^{\text {nd }}$ International Conference on Global Development - ICODEV

December $5^{\text {th }}, 2020$, Online Conference

social role of to' mappakianak (traditional midwives) in the village. Half of the midwives stated that the number of $t o^{\prime}$ mappakianak was only one person per village, although it turns out that there were still villages that have more than five to' mappakianak and who still helped on childbirth proccess. Age of to'mappakianak were all old (more than 50 years old) and only acts as an ordinary role as baby assistance. In addition, the existence of other health workers who assist midwives in the village were also important.

\section{2) Communication category}

Second category could be seen on Table 4. Good communication from midwives in providing health services and counseling were quite important. The time for giving pregnancy classes with special classes outside of Posyandu activities had been increased after the training was given. The materials for the pregnancy classes in the Sa'dan sub-district were generally exercise for pregnant women and health promotion, of which only part of the region have carried out routine per month. The correct recording's activities during the Posyandu activities that were also considered.

Communication with pregnant women and families in the community, midwives still infacing the seniority, but midwives had taken a good approach and continue to provide the correct explanations. Apart from that, efforts were needed to create a sense of security and comfort during childbirth, and established inter-sectorals communication for delivery services.

\section{3) Values and attitudes category}

Values and attitudes category could be seen on Table 5. The values and attitudes adopted by midwives regarding pregnancy and childbirth on the pre-test measurement were positive, this could be seen from the statements they wrote in the questionnaire. These positive values and attitudes could be maintained after intervention in the form of cultural competency training. It was expected that during the pre-test, these positive values and attitudes were only limited to normative understanding, but after they attended the training, they became internalized in every health worker. This was possible because in addition to get an understanding of culture and communication, during the training, they also doing roleplay so that they could really feel the importance of running a safe pregnancy and childbirth program.

Assessment cultural competence of midwives related to values and attitudes, consist of:

a) Attitude infacing pregnant woman who tending self delivery at home;

b) Infacing taboos which were influenced to pregnant woman's health;

c) Value of having many children;

d) Attitude to pregnancy seen as an ordinary situation; and

e) These four assessment's items indicated that the values and attitudes of midwives in providing cultural competency in maternal and child's health services were quite good.

\section{E. Cultural Competency in Maternal and Child's Health Services}

Cultural competency in health service was a set of congruent behaviors, attitudes, and policies that come together in a system, agency, or among health professionals that enables effective work in cross-cultural situations.
Culture had meaning of integrated patterns of human behavior, which include language, thoughts, communications, actions, customs, beliefs, values, and institutions of racial, ethnic, religious, or social groups. Competency had the meaning of having the capacity to function effectively as an individual health workers and a health system organization within the context of the cultural beliefs, behaviors, and needs presented by health worker professionals and their communities.

Cultural competency actually had multidimension facets. First dimension of culturally specific attributes that included of main ethnic groups, other diffrent ethnic groups, sexual orientation, gender orientation, socioeconomic status, education level, and geographic location. Second dimension was elements of cultural competency that included of cultural awareness, cultural knowledge, and culturally appropriate clinical skills. To provide cultural responsiveness on health services, health workers need to aware of their own attitudes, beliefs, biases, and assumptions about others. Gaining cultural knowledge of the populations and obtaining specific cultural knowledge as it relates to help-seeking, treatment, and recovery. This dimension also involves competence in clinical skills that ensure delivery of culturally appropriate treatment interventions. Third dimension was foci of culturally responsiveness that targeted key levels of health services from individual, clinical and administrative level. Interventions need to occur at each of these levels to provide culturally responsiveness on health services[5].

Midwives' cultural understanding were very important, even though midwives came from the same ethnic as the local community. It was midwives' education which differentiated their understanding from ordinary people in the village. Cultural understanding was important because culture could influenced the concept of meanings of health and illness, how humans explained the concept of disease, health-seeking behavior, the useful functions of the health system, relationships with health care providers, and the acceptance of modern medical treatment.

Cultural competency training was expected that midwives would have (1) the ability to deal effectively with people from different cultural backgrounds; (2) knowledge, attitudes, and behavior to improve the quality of services for people with certain cultures, by accepting and respecting the different concepts, namely between the concept of health programs and the concept of health culture in the community.

In 2017, a year before this cultural competency training established, scoring of cultural competence of village midwives also held in Sa'dan Sub District. The result in 2017 bringing up the themes of role play. It showed generally quite good in terms of understanding the physical environment, material and resources (71.4\%), communication style (57.1\%), values and attitudes (57.1\%), and interpersonal interactions $(71.4 \%)$. There is still a need to improve the cultural competence of village midwives because there is still a value for lack of understanding of the physical environment, materials and resources $(28.6 \%)$, communication styles $(42.9 \%)$, values and attitudes $(42.9 \%)$, and interpersonal interactions $(28.6 \%)$. It is necessary to improve the communication style and attitude value of the village midwives[1]. Comparison with the result in 2018, which were 
The $2^{\text {nd }}$ International Conference on Global Development - ICODEV

December $5^{\text {th }}, 2020$, Online Conference

targeting to all midwives (Midwife coordinator, Village Midwives, and internship Midwives) in the Sa'dan subdistrict with three categories of cultural competency assessment, namely (1) physical, material and resource environmental conditions; (2) communication; and (3) values and attitudes, were considered to have improved very well before and after the training. This was because throughout 2017-2018 the researcher also provided assistance and advocacy to policy makers and inter sectors for safe delivery efforts [1][2].

The most important aspect in improving cultural competence was the understanding of local cultural concepts. The definition related to the concept of culture must be used as a first step in understanding the complexity and dynamics of community's culture. Discussing the definition of local cultural concepts would reflect the challenges, contradictions and ambiguities in line with cultural concepts as health workers. The understanding would become culturally competency.

Cultural competency was knowledge, attitudes, and behavior to improve the quality of service to community with certain cultures by accepting and respecting the differences in concepts, namely between the concept of health program and the concept of health culture in community. Competence was an ongoing process that involves accepting and respecting differences in beliefs that affected different individual's views of life. Cultural competence involved general cultural information as well as specific culture so that midwives had a cultural understanding in dealing with community with certain local cultures [6].

Cultural competency in maternal and child's health service was the understanding cultural influences on pregnat women and family's health beliefs and behaviors [7]. All those cultural factors related to how the health services provider interacted to the community with certain culture.

\section{CONCLUSION}

Understanding cultural competence was a continuous process and builds increased cultural knowledge. In order to achieve a higher level of competence, it is very important to carry out a self-assessment. Self-assessment provides direction for development. Open communication was the foundation of culturally competency in health services.

Cultural competency training for midwives at the Sa'dan Primary Health Center could be a pilot model for development in other sub-districts in North Toraja District, and could be broader for other health workers' training.

Village midwives' understanding that were the target of cultural competency training. The problems of cultural barriers which were exist in society, could have a negative impact on maternal pregnancy and unsafe delivery. Realizing that maternal and child health problems were not purely the sole responsibility of the village midwife, but could involve the whole community and local cross-sectors for joint to increase understanding of safe pregnancy, safe delivery, mother and baby living safely and healthy. With good communication from health service providers to the community so that they did not feel like working alone in the village.

On the next level, in line with improving midwives' cultural competency, it's also important to improve community participation in overcoming the community health problems. By sharing peer to peer knowledges on various occasions, assisted by midwives, health cadres and other sectors. It was hoped that in the community there would be a learning process together to increase the public awareness that pregnancy and delivery which not assisted by health worker professionals and not carried out in health care facilities pose a risk to the safety live of mothers and/or babies.

\section{ACKNOWLEDGEMENT}

The author would like to thank to the Head of the Center for Humanities and Health Management Research and Development for supporting the research. Also thank to The Regent of North Toraja, the Head and Staffs of North Toraja's Regency of Public Health and Services, the Head of the Sa'dan Primary Health Center and Midwives for the active involvement and supporting during the research conducted.

\section{REFERENCES}

[1] W. Lestari, Z. Auliyati, R. Ristrini, S. Suriah, and A. Yani, "Intervensi Kesehatan Ibu dan Anak Terkait Persalinan Aman Berbasis Budaya Etnis Toraja di Sa'dan Toraja Utara (Tahap I)," Laporan Penelitian, Surabaya: P3HMK, 2017.

[2] W. Lestari, Z. A. Agustina, R. Ristrini, S. S. Hartiningsih, and Y. Luthfiana, "Intervensi Kesehatan Ibu dan Anak Terkait Persalinan Aman Berbasis Budaya Etnis Toraja di Sa'dan Toraja Utara (Tahap II)," Laporan Penelitian, Surabaya:P3HKM, 2018.

[3] Badan Penelitian dan Pengembangan Kesehatan, "Riskesdas 2013 Dalam Angka," Jakarta, 2013.

[4] W. Lestari, M. Soleha, I. Ibrahim, Ruwaedah, and B. Roosiehermiatie, Buku Seri Riset Etnografi Budaya Kesehatan Ibu dan Anak, Etnik Toraja Sa'dan Kabupaten Toraja Utara. Surabaya: Pusat Humaniora Kebijakan Kesehatan dan Pemberdayaan Masyarakat, 2012.

[5] Substance Abuse and Mental Health Services Administrations (SAMHSA), or the U. S. Department of Health. and Human Services (HHS), Improving Cultural Competence Quick Guide For Clinicians. SAMHSA, 2014.

[6] M. Sutton, "Improving patient care: cultural competence," Fam Pr. Manag, vol. 7, no. 9, pp. 58-60, 2000.

[7] J. R. Betancourt, A. R. Green, J. E. Carrillo, and O. Ananeh-Firempong, "Defining cultural competence : a practical framework for addressing racial / ethnic disparities in health and health care," Public Health Rep., vol. 118, pp. 293-302, 2003. 